\title{
Penyalahgunaan Internet Sewaktu Kuliah: Kesan daripada Penyerapan Kognitif dan Tabiat Berinternet
}

(Cyber Slacking During Lecture: The Effect of Cognitive Absorption and Internet Habit)

\author{
Roshayati Abdul Hamid \\ Zaleha Yazid \\ Noor Hasni Juhdi \\ Laila Adrena Mat Kana
}

(Fakulti Ekonomi dan Pengurusan, Universiti Kebangsaan Malaysia)

\begin{abstract}
ABSTRAK
Fenomena penyalahgunaan internet dalam kalangan pelajar terjadi apabila pelajar menggunakan internet bagi tujuan lain selain daripada aktiviti berkaitan pembelajaran sewaktu kuliah. Penyalahgunaan internet mampu memberi kesan yang negatif kepada pelajar dan universiti dalam melahirkan graduan yang bertaraf dunia. Penyerapan kognitif adalah motivasi intrinsik yang mampu mempengaruhi tingkahlaku pelajar apabila mereka terlibat secara mendalam dengan teknologi internet. Penyerapan kognitif boleh menyebabkan pelajar tersebut merasai seperti terputus daripada realiti, mempunyai tahap rasa ingin tahu yang tinggi, keseronokan yang melampau, fokus yang mendalam dan hilang kawalan. Oleh itu, kajian ini bertujuan untuk menguji samada penyalahgunaan internet sewaktu kuliah didorong oleh penyerapan kognif pelajar tersebut. Kajian ini juga ingin menguji tabiat berinternet sebagai pembolehubah peyederhana. Borang soal selidik telah diedarkan kepada pelajar Institusi Pengajian Tinggi di Malaysia. Data mentah yang diperoleh telah dianalisis menggunakan SPSS. Hasil kajian mendapati penyerapan kognitif dan tabiat berinternet mempunyai hubungan yang signifikan dengan penyalahgunaan internet, namun tabiat berinternet tidak menyederhanakan hubungan antara penyerapan kognitif dan penyalahgunaan internet.
\end{abstract}

Kata kunci: Penyalahgunaan internet; penyerapan kognitif; tabiat berinternet; institusi pengajian tinggi.

\section{ABSTRACT}

The phenomenon of cyber slacking occurs when students use the internet for other purposes other than learning related activities during lecture. Cyber slacking may have negative impact on students and the university in producing world-class graduates. Cognitive absorption is an intrinsic motivation that may influence students' behavioral when they deeply involved with internet technology. Cognitive absorption may cause the student to feel as temporal dissociation, has a high degree of curiosity, heightened enjoyment, immersive focus and loss of control. Therefore, the purpose of this study is to examine whether cyber slacking during lecture is driven by student's cognitive absorption. In addition, the internet habit is also being tested as a moderator variable. Questionnaires were distributed to students at Higher Education Institution in Malaysia. The raw data obtained was analyzed using SPSS. The findings showed that cognitive absorption and internet habit have significant relationships with cyber slacking, but internet habit do not moderate the relationship between cognitive absorption and cyber slacking. 
Keywords: Cyber slacking; cognitive absorption; internet habit; higher education institution

\section{PENGENALAN}

Pengunaan internet bagi tujuan pengajaran dan pembelajaran semakin meningkat di Institusi Pengajian Tinggi (IPT) sejajar dengan perkembangan teknologi dan revolusi industri 4.0. Menurut laporan Suruhanjaya Komunikasi dan Multimedia Malaysia, terdapat peningkatan pengunaan internet dalam kalangan pelajar IPT iaitu daripada $36.7 \%$ pada tahun 2016 kepada 44.6\% pada tahun 2018 (MCMC 2018). Pihak IPT juga telah menyediakan talian internet tanpa wayar (wireless internet atau $\mathrm{WiFi}$ ) untuk kemudahan pelajar dalam pembelajaran dan pengajaran. Tambahan pula dengan kemampuan pelajar untuk memiliki peranti teknologi peribadi seperti telefon pintar, komputer riba dan tablet yang membolehkan internet diakses secara meluas tanpa mengira tempat dan masa.

Pelajar IPT memperolehi banyak manfaat daripada pengunaaan internet dalam pengajaran dan pembelajaran di universiti. Terdapat bahan bacaan dan buku rujukan yang mudah dicapai, maklumat pembelajaran yang efektif dan terkini seperti berita semasa, memudahkan komunikasi dan interaksi antara pelajar dengan pensyarah dan rakan pelajar lain serta berkongsi maklumat dengan cepat dan pantas (Apuke \& Iyendo 2017; Lam \& Tong 2012). Dalam hal ini, pelajar kerap menggunakan platform perkongsian kandungan atas talian (online content sharing platform) iaitu media sosial yang mempunyai beberapa akaun jaringan sosial seperti Muka Buku (Facebook), Whatsapp, Instagram, Skype,You Tube, Twitter, Google +, Linkedin dan sebagainya.

Namun disebalik manfaat yang diperolehi daripada penggunaan internet, ianya juga mampu mendatangkan kemudaratan jika pelajar menyalahgunakannya. Pelajar IPT sering melayari internet sewaktu kuliah dengan mengakses laman sesawang yang tiada kaitan dengan aktiviti pembelajaran. Fenomena ini dikenali sebagai penyalahgunaan internet (cyber slacking) (Gerow, Galluch \& Thatcher 2010). Beberapa kajian terdahulu telah membuktikan bahawa penyalahgunaan internet sewaktu kuliah boleh menganggu tumpuan pelajar terhadap proses pembelajaran yang sedang berjalan. Pelajar sukar memahami apa yang diajar dan mengambil mudah terhadap tugasan yang diberikan (Gerow et al. 2010; Ravizza, Hambrick \& Fenn 2014; Soh, Koay \& Lim 2018). Seterusnya, boleh mengakibatkan kejatuhan prestasi akademik pelajar. Masalah penyalahgunaan internet yang berterusan bukan sahaja memberi kesan negatif kepada pelajar tetapi juga kepada produktiviti universiti dalam melahirkan graduan yang bertaraf dunia.

Secara umumnya, pelajar terdorong untuk mengakses internet bagi tujuan peribadi berbanding tugas hakiki sewaktu kuliah kerana dipengaruhi oleh beberapa faktor luaran dan dalaman (Lim \& Chen 2012; Young 2006) yang juga disebut sebagai motivasi ekstrinsik (luaran) dan intrinsik (dalaman). Antaranya adalah norma sosial (Rana et al. 2016), kemudahan internet (Henle \& Blanchard 2008), ketidakpuasan (Vitak, Crouse \& LaRose 2011), lokus kawalan (Chen, Chen \& Yang 2008), keupayaan pelbagaian (multitasking ability) (Gerow et al. 2010), mempunyai pengalaman dalam berinternet (Baturay \& Toker 2015), tabiat berinternet (Hasmida et al. 2015; Vitak et al. 2011) dan ketagihan berinternet (Bonetta et al. 2019).

Kajian lepas lebih tertumpu kepada faktor dorongan luaran yang mana ia lebih mudah ditangani berbanding faktor dorongan dalaman. Justeru, kajian ini memfokus kepada motivasi intrinsik kerana ianya merupakan sikap (kognitif dan afektif) yang akan menentukan tingkahlaku individu. Kognitif adalah berkaitan dengan proses berfikir iaitu keupayaan berfikir (Ostrom 1969), manakala afektif pula adalah berkaitan dengan emosi dan perasaan (Ostrom 1969). Komponen kognitif dan afektif adalah saling berkait kerana ianya merupakan 
komponen sikap manusia dan konsisten dengan tingkahlaku. Menurut Teori Regulasi-Kendiri (Self-Regulation Theory), terdapat tingkahlaku yang mudah dan yang sukar untuk dikawal oleh individu itu sendiri (LaRose, Lin \& Eastin 2003). Tingkahlaku individu sukar untuk dikawal apabila ianya menjadi suatu perbuatan yang dibuat tanpa disedari (unconscious) seperti tabiat dan tabiat yang berulang yang mampu menjadi ketagihan (addiction) (Tokunaga 2017).

Oleh itu, kajian ini ingin menguji sejauhmana penyerapan kognitif (cognitive absorption) mampu mempengaruhi tingkahlaku pelajar dalam penyalahgunaan internet sewaktu kuliah dan tahap kawalan tingkah laku ini seperti yang dinyatakan dalam Teori Regulasi-kendiri. Penyerapan kognitif merupakan motivasi intrinsik yang didefinisikan sebagai penglibatan mendalam seseorang terhadap sesuatu yang dilakukan terutama dalam hal yang berkaitan dengan penggunaan teknologi (Agarwal \& Karahanna 2000). Selain dari penyerapan kognitif, kajian ini juga menguji tabiat berinternet sebagai pembolehubah penyederhana dalam hubungan antara penyerapan kognitif dengan penyalahgunaan internet. Tabiat berinternet juga merupakan motivasi intrinsik dan telah terbukti sebagai perbuatan berulang yang berlaku secara automatik dan berlaku tanpa disedari (Tokunaga \& Rains 2016).

\section{ULASAN KAJIAN LEPAS}

\section{PENYALAHGUNAAN INTERNET (CYBERSLACKING)}

Penyalahgunaan internet telah menjadi satu tren dalam kalangan pelajar universiti dan merupakan satu gangguan terutamanya kepada pelajar sewaktu kuliah. Penyalahgunaan internet sewaktu kuliah boleh didefinisikan sebagai penggunaan internet ketika di dalam kelas untuk tujuan selain daripada aktiviti berkaitan dengan pembelajaran (Gerow et al. 2010). Antara perkataan popular yang digunakan dalam kajian lepas selain penyalahgunaan internet (cyberslacking) adalah cyber-slouching (Urbaczewski \& Jessup 2002), cyber loafing (Lim 2002), non-work related computing (Lee, Lim \& Wong 2005) dan personal internet use (Hasmida et al. 2015). Walaupun penggunaan kata kunci yang berbeza namun, kesemuanya menggambarkan perkara yang sama iaitu penggunaan internet yang tidak produktif ketika melakukan tugas hakiki seperti sedang bekerja atau semasa kuliah sedang berlangsung.

Kebanyakan universiti telah menyediakan internet tanpa wayar bagi tujuan menyokong pembelajaran di dalam kuliah (Henderson, Kotz \& Abyzov 2004). Hal ini terutamanya memudahkan pelajar untuk memuat turun bahan rujukan yang diberikan oleh pensyarah atau mengambil peperiksaan dan kuiz atas talian (Shotsberger \& Vatter 2001). Walau bagaimanapun, kerap kali pelajar tidak dapat memberikan tumpuan terhadap pembelajaran kerana lebih tertumpu kepada aktiviti lain dengan menggunakan internet (Kuznekoff, Munz \& Titsworth 2015; Ravizza et al. 2014; Young, 2006). Antara contoh penyalahgunaan internet sewaktu kuliah ialah bermain permainan atas talian, menonton video atas talian, menghantar e-mel peribadi, mengemas kini status ke akaun jaringan sosial, blogging, berinterkasi atas talian dengan kenalan dan saudara serta membeli belah secara atas talian (McCoy 2016; Ravizza et al. 2014; Soh et al. 2018; Weatherbee 2010).

Penggunaan internet sewaktu kuliah bukan sahaja boleh menganggu sesi pembelajaran pelajar tersebut tetapi juga pelajar lain serta pensyarah yang mengajar (Flanigan \& Kiewra 2018; Ravizza et al. 2014; Soh et al. 2018). Malah, terdapat beberapa pensyarah bertindak menghalang penggunaan peranti teknologi peribadi yang boleh mengakses internet sewaktu kuliah. Pelajar yang membawa peranti teknologi mereka harus menyahaktifkan peranti tersebut bagi mengawal penggunaan internet yang tidak berkaitan dengan pembelajaran (Bugeja 2007; Soh et al. 2018). Kajian terdahulu juga mendapati penyalahgunaan internet 
sewaktu kuliah mampu meransang tabiat yang berterusan di masa hadapan terutama sewaktu pelajar memasuki alam pekerjaan kelak (Soh et al. 2018)

Kajian terdahulu telah mengkaji mengenai beberapa peramal (predictor) penyalahgunaan internet dalam kalangan pelajar IPT (contoh, Baturay \& Toker 2015; Currie 2015; Flanigan \& Kiewra 2018; Gerow et al. 2010; Soh et al. 2018; Yasar \& Yurdugul 2013). Pelajar IPT terdorong dalam penyalahgunaan internet kerana merasakan pengalaman yang cukup luas dalam berinternet (Baturay \& Toker 2015) membuatkan mereka menjadi ketagih (addicted) dengan teknologi yang canggih itu (Yasar \& Yurdegul 2013). Mereka juga tidak mampu untuk mengawal aktiviti atas talian (Shannon 2011) kerana mempunyai lokus kawalan luaran yang tinggi tetapi rendah dalam harga diri (self-esteem) (Chen et al. 2008). Pelajar IPT lebih gemar meluangkan masa berkomunikasi dengan kawan-kawan, saudara mara atau sesiapa sahaja melalui internet kerana mereka merasakan ianya suatu perkara yang biasa iaitu norma sosial masa kini (Hsu \& Lin 2017). Justeru, penglibatan pelajar IPT yang mendalam dengan internet mampu mewujudkan ikatan kognitif (cognitive engagement) yang menyukarkan mereka untuk mengawal diri dari penyalahgunaan internet sewaktu kuliah (Gerow et al. 2010).

\section{TEORI REGULASI-KENDIRI (SELF-REGULATION THEORY)}

Teori Regulasi-kendiri pertama kali diperkenalkan oleh Bandura (1991) melalui Teori Kognitif Sosial bagi menerangkan tingkahlaku individu yang kadang kala tidak mampu untuk mengawal diri sendiri. Bandura (1991) telah menyatakan mekanisme regulasi-kendiri beroperasi menggunakan tiga prinsip iaitu permerhatian-kendiri, pertimbangan mengenai tingkahlaku seseorang dan reaksi-kendiri. Menurut beliau lagi, kebanyakan tingkahlaku manusia mempunyai tujuan dan diregulasikan dengan pemikiran. Tambahnya lagi, efikasikendiri memainkan peranan utama didalam regulasi-kendiri. Manusia percaya efikasi yang dimiliki berupaya mempengaruhi pilihan yang mereka buat, memberi aspirasi, memperuntukan berapa banyak usaha yang mampu digunakan, sejauhmana mereka mampu bertahan dalam menghadapi kesulitan; sama ada mengelakkannya atau membantu diri sendiri, jumlah tekanan yang mampu diterima dalam mengatasi permintaan yang tinggi dan kerentanan kepada kemurungan (Bandura 1991).

LaRose et al. (2003) telah mengaplikasi teori regulasi-kendiri Bandura (1991) dalam kajian mereka dengan menambah komponen kelemahan (deficiency). Sebuah model teoretikal mengenai penggunaan media yang tidak terkawal dibangunkan dimana simpton ini dipanggil "ketagihan media". Ianya digunakan sebagai mengukur kelemahan individu dalam mengawal diri mereka ketika menggunakan internet (LaRose et al. 2003). Kelemahan di dalam regulasi-kendiri ini boleh menyebabkan pembentukan tabiat atau kes yang lebih ekstrim iaitu patologi. Kelemahan regulasi-kendiri boleh mempengaruhi pelajar untuk menyalahgunakan internet sewaktu kuliah bagi melayari perkara yang tidak berkaitan dengan pembelajaran (Currie 2015).

Namun, tidak semua kelemahan regulasi-kendiri ini boleh diklasifikasikan sebagai 'ketagihan media'. Malah, Teori Kognitif Sosial juga ada menyatakan bahawa terdapat pelbagai tahap di dalam regulasi-kendiri dan tidak semestinya kelemahan mengawal menyebabkan 'ketagihan media' (LaRose et al. 2003). Kajian ini juga melihat sama ada penyerapan kognitif adalah satu tingkahlaku yang boleh menyebabkan kelemahan regulasikendiri dan seterusnya adakah ianya mendorong kepada 'ketagihan media' kerana terdapat kajian yang menyatakan bahawa penyerapan kognitif memberi kesan terhadap ketagihan internet (Barnes \& Pressey 2014; Jia 2012). 


\section{PENYERAPAN KOGNITIF (COGNITIVE ABSORPTION)}

Penyerapan kognitif menggambarkan pengalaman interaktif menyeluruh antara individu dan internet. Terdapat beberapa kajian yang membuktikan hubungan antara penyerapan kognitif dan internet. Antaranya ialah kajian yang mendapati keperluan dan kemampuan media sosial sebagai pendorong kepada penyerapan kognitif (Hsu \& Lin 2017). Penyerapan kognitif juga sering dikaitkan dengan pendorong kepada penggunaan internet yang bermasalah (problematic internet) (Bazogian, Demirer \& Sahin 2014), pendorong kepada kebolehgunaan dan kebergunaan jaringan sosial (Hsu et al. 2016) serta pembolehubah pengantara antara kemahiran tugasan berbilang (multitasking) dengan penyalahgunaan internet (Gerow et al. 2010).

Penyerapan kognitif merujuk kepada keadaan dimana seseorang itu sangat khusyuk dengan aktiviti atas-talian yang dilakukannya (Hsu \& Lin 2017) sehingga terputus daripada realiti (temporal dissociation), memberi fokus yang mendalam (immersion focus), merasai keseronokan yang tinggi (heightened enjoyment), mempunyai perasaan ingin tahu yang tinggi (curiosity) dan kawalan (control) (Agarwal \& Karahanna 2000). Dalam kajian ini, penyerapan kognitif dikonseptualisasikan sebagai penglibatan yang mendalam seseorang pelajar didalam teknologi internet.

Sekarang ini, banyak aplikasi dalam internet yang direka untuk menarik perhatian seseorang individu. Salah satunya adalah permainan yang boleh dimuat turun serta boleh mencabar dan dicabar oleh individu lain untuk pemarkahan yang paling tinggi. Pelajar yang berminat dengan aplikasi tersebut kadang kala bermain tanpa mengira tempat walaupun di dalam kelas (Kubey \& Csikszentmihalyi 2002). Pelajar boleh menjadi terlampau taksub berinteraksi di alam maya sehingga mereka leka serta boleh menghabiskan masa yang tidak dirancangkan untuk berinternet. Tingkahlaku ini dikenalpasti sebagai terputus dari realiti (temporal dissociation) yang merupakan salah satu dari elemen penyerapan kognitif (Agarwal \& Karahanna 2000; Mazzoni, Cannata \& Baiocco 2016). Elemen yang kedua di dalam penyerapan kognitif ialah fokus yang mendalam (immersion focus) dimana pelajar terlampau memberikan tumpuan kepada permainan internet sehingga menyekat gangguan lain, sukar untuk mengubah tumpuan serta kawalan diri (Mazzoni et al. 2016).

Selain itu, menurut Agarwal \& Karahanna (2000) dan Gerow et al. (2010), pelajar yang merasa seronok menggunakan teknologi internet untuk berbual (chatting) bersama dengan kenalan atau saudara lebih mudah leka dengan aktiviti tersebut sehingga mereka merasakan ianya adalah suatu aktiviti yang memberikan keseronokan yang tinggi (heightened enjoyment). Malah, apabila terlampau tertumpu kepada mesej segera (instant messaging) atau whatsapp, seseorang individu itu sedang melalui pengalaman yang menyeronokan sehingga tidak sedar masa yang berlalu (Gerow et al. 2010). Hal ini boleh menyebabkan penyalahgunaan internet terus meningkatkan tanpa mengira masa dan tempat.

Pelajar juga berpendapat, berinternet dapat menimbulkan rasa ingin tahu (curiosity) (Agarwal \& Karahanna 2000) yang melampau. Justeru, pelajar dapat memanafaatkan pengalaman yang diperoleh dari sumber-sumber internet untuk menjawab persoalan yang mereka inginkan. Kebanyakan persoalan-persoalan yang pelajar ingin tahu adalah lebih tertumpu kepada sesuatu yang peribadi berbanding sesuatu yang akademik. Manakala, elemen terakhir penyerapan kognitif iaitu kawalan (control) (Agarwal \& Karahanna 2000) dalam diri sendiri ketika terlibat dalam berinteraksi dengan seseorang atau sesuatu. Kebanyakan pelajar mengaku mereka sebenarnya tidak dapat mengawal penggunaan internet terutama ketika mereka sedang berinteraksi dengan kenalan melalui internet atau melakukan aktiviti hiburan.

Berdasarkan beberapa kajian lepas mengenai penyerapan kognitif dan penyalahgunaan internet, kajian ini telah membangunkan hipotesis yang pertama: 
$\mathrm{H}_{1}$ Terdapat hubungan yang signifikan antara penyerapan kognitif dengan penyalahgunaan internet.

\section{TABIAT BERINTERNET}

Tabiat merujuk kepada sifat dalaman seseorang yang mempengaruhi fikiran atau perbuatannya (Kamus Pelajar Bahasa Melayu Dewan 2012). Tabiat adalah tingkahlaku yang terjadi tanpa memerlukan pembuatan keputusan dalam memberi maklumbalas terhadap sesuatu (Triandis 1980). Kekerapan dan kebiasaan seseorang itu mengakses internet untuk mendapatkan maklumat, bermain permainan atas talian atau berkomunikasi melalui media sosial, berkemungkinan menyebabkan individu tersebut meneruskan perbuatannya tanpa mengira masa dan tempat, ianya berlaku secara automatik dan tanpa disedari (Moody \& Siponen 2013). Fenomena ini disebut sebagai tabiat berinternet.

Tabiat berinternet adalah tindakbalas yang berlaku secara automatik dan tanpa disedari terhadap petunjuk (cues) dalaman atau luaran dari penggunaan internet yang berterusan. Tabiat berinternet boleh terbentuk dengan penggunaan internet yang bertujuan atau tanpa tujuan yang jelas (Davis 2001). Tabiat berinternet yang bertujuan adalah tindakbalas terhadap kandungan dan platform internet yang spesifik seperti permainan atas talian, menonton video yang tidak senonoh, berkomunikasi melalui media sosial, mendapatkan maklumat mengenai berita semasa dan sebagainya (Tokunaga 2017). Justeru, segala aktiviti yang menggunakan internet, berlaku secara kerap, rutin dan berterusan serta tanpa disedari boleh diklasifikasikan sebagai tabiat berinternet.

Hasil kajian terdahulu mendapati tabiat berinternet mampu mendorong kepada penyalahgunaan internet kerana tabiat berinternet adalah satu tingkahlaku yang dilakukan tanpa disedari (Pee, Woon \& Kankanhalli 2008; Soh et al. 2018; Vitak et al. 2011). Apabila individu menggunakan internet secara kerap, rutin dan berterusan dalam apa jua urusan, mereka tidak perlu mempertimbangkan implikasinya, mereka tidak perlu mempersoalkan tingkalaku tersebut betul atau salah, malah ianya telah menjadi satu norma sosial (Askew et al. 2014). Maka, individu yang mempunyai tabiat berinternet ini adalah terdedah untuk melakukan penyalahgunaan internet tanpa disedari sama ada di pejabat bagi mereka yang bekerja atau semasa kuliah bagi mereka yang sedang belajar.

Kekuatan tabiat berinternet juga boleh meningkat apabila tingkahlaku tersebut berlaku tanpa kawalan (LaRose 2010) terutama ketika seseorang itu berada dalam situasi kemurungan, kesunyian, ketidakpuasan dan kebosanan (LaRose, Kim \& Peng 2010). Tabiat berinternet juga berperanan sebagai pembolehubah peyederhana dimana tabiat berinternet melemahkan hubungan diantara gratifikasi dengan hasrat menggunakan internet secara berterusan (Chiu \& Huang 2015). Dalam kajian tersebut, tabiat berinternet adalah tingkahlaku yang tidak disedari manakala gratifikasi adalah pertimbangan yang disedari. Oleh itu, kajian ini juga berminat untuk menguji tabiat berinternet sebagai pembolehubah peyederhana yang mampu menguatkan hubungan antara penyerapan kognitif dan penyalahgunaan internet. Memandangkan penyerapan kognitif adalah suatu tingkahlaku yang sukar dikawal dan tabiat berinternet pula adalah tingkahlaku yang tidak disedari, maka interaksi penyerapan kognitif dan tabiat dalam penggunaan internet dijangka dapat mempengaruhi penyalahgunaan internet sewaktu kuliah.

Berdasarkan beberapa kajian lepas mengenai tabiat berinternet, kajian in telah membangunkan hipotesis yang kedua dan ketiga:

$\mathrm{H}_{2}$ Terdapat hubungan yang signifikan antara tabiat berinternet dengan penyalahgunaan internet. 
$\mathrm{H}_{3}$ Hubungan antara penyerapan kognitif dan penyalahgunaan internet disederhanakan oleh tabiat berinternet. Jika tabiat berinternet tinggi, maka hubungan tersebut menjadi lebih kuat dan sebaliknya.

\section{RANGKA KERJA KAJIAN}

Hasil daripada beberapa sorotan lepas, kajian ini telah membangunkan tiga hipotesis yang menguji hubungan antara penyerapan kognitif dengan penyalahgunaan internet serta peranan tabiat berinternet sebagai pembolehubah penyederhana hubungan di atas. Hipotesis-hipotesis yang telah dibangunkan boleh digambarkan melalui rangka kerja kajian seperti di bawah.

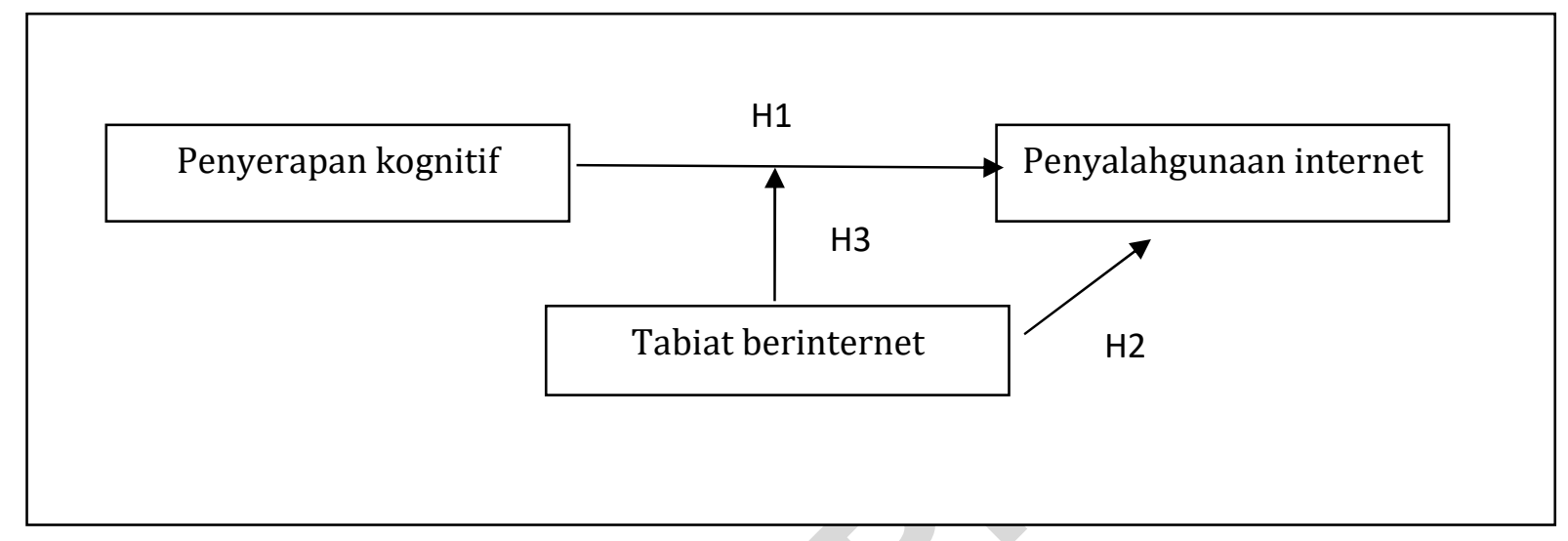

RAJAH 1. Hubungan antara penyerapan kognitif dan penyalahgunaan internet yang disederhanakan oleh tabiat berinternet.

\section{METODOLOGI KAJIAN}

Kajian ini berbentuk soal selidik (survey) dimana borang soal selidik digunakan sebagai kaedah pengumpulan data untuk menilai persepsi responden mengenai penyalahgunaan internet sewaktu kuliah. Borang soal selidik yang ringkas dilakukan agar responden mudah untuk memahami soalan yang dinyatakan seterusnya dapat meningkatkan kadar soalan yang dijawab serta mengurangkan ralat (Fanning 2005).

Untuk mencapai objektif kajian, pelajar IPT di Malaysia telah dipilih sebagai responden. Oleh itu, populasi kajian ini adalah kesemua pelajar IPT yang memegang status warganegara Malaysia kerana soal selidik yang disediakan adalah dalam Bahasa Melayu. Kaedah persampelan yang digunakan adalah kaedah persampelan mudah (convenience sampling) dimana borang soal selidik telah diedarkan kepada para pelajar melalui atas talian (online) menggunakan google form dan juga luar talian (offline) dimana borang diagihkan secara terus kepada responden. Persampelan mudah digunakan dalam kajian ini kerana ianya merupakan kaedah persampelan yang dapat meminimumkan kos, menjimatkan masa dan yang paling penting sekali populasi yang diperlukan adalah mudah dicapai serta ketersediaan untuk melibatkan diri dalam kajian adalah tinggi (Saunders, Lewis \& Thornhill 2012).

Borang soal selidik ini dibahagikan kepada empat (4) bahagian. Bahagian A adalah profil demografi yang menfokuskan kepada profil responden iaitu terdiri daripada jantina, kumpulan umur, peringkat pengajian dan institusi pengajian tinggi. Bahagian B pula menfokuskan kepada soalan mengenai penyalahgunaan internet. Soalan dalam bahagian ini diadaptasikan dari kajian Gerow et al. (2010) seperti "Saya melayari internet untuk berhubung dengan kenalan dan saudara semasa kuliah". Soalan ini menggunakan skala Likert 
5 dimana 1 ialah tidak pernah dan 5 ialah sentiasa. Bahagian $\mathrm{C}$ adalah soalan untuk pembolehubah penyederhana iaitu tabiat berinternet yang diadaptasikan dari kajian Pee et al. (2008) seperti "Apabila saya hendak memuat-turun sesuatu yang tidak berkaitan dengan pembelajaran, secara automatik saya menggunakan internet yang disediakan oleh pihak universiti". Soalan ini menggunakan skala Likert 5 dimana 1 ialah tidak pernah dan 5 ialah sentiasa.

Manakala bahagian D adalah bahagian yang menfokuskan kepada penyerapan kognitif, terdapat 19 soalan secara menyeluruh. Dalam kajian ini, penyerapan kognitif diukur sebagai pembolehubah formatif dan soalan pengukuran diadaptasikan daripada kajian Agarwal dan Karahanna (2000) seperti "Saya rasa kelas berakhir dengan pantas apabila saya mengunakan internet" untuk elemen terputus dari realiti dan "Penggunaan internet dapat meransangkan perasaan ingin tahu" untuk elemen rasa ingin tahu. Kesemua elemen-elemen penyerapan kognitif ini diukur menggunakan skala Likert 5 dimana 1 ialah sangat tidak setuju dan 5 ialah sangat setuju.

Data mentah dianalisis menggunakan Statistical Package for Social Science (SPSS) dan beberapa jenis analisis telah dijalankan seperti analisis kekerapan, statistik deskriptif, kolerasi Pearson, kebolehpercayaan, dan regresi berganda. Analisis kebolehpercayaan yang digunakan ialah Cronbach's alpha untuk mengukur ketekalan dalaman item di dalam borang soal selidik (Johns 1992). Analisis kekerapan pula dapat membantu pengkaji untuk menganalisis taburan kekerapan responden (Niaei, Peidaei \& Nasiripour 2014) dan analisis kolerasi adalah untuk mengukur hubungan linear antara pembolehubah penyerapan kognitif, tabiat berinternet dan penyalahgunaan internet. Akhir sekali, analisis regresi digunakan untuk melihat samada terdapat hubungan yang signifikan antara pembolehubah penyerapan kognitif dan pembolehubah penyalahgunaan dan seterusnya regresi berganda untuk mengenalpasti samada pembolehubah peyederhana iaitu tabiat berinternet dapat menyederhanakan hubungan antara penyerapan kognitif dan penyalahgunaan internet.

\section{HASIL KAJIAN}

Kajian ini menumpukan kepada faktor penyalahgunaan internet dalam kalangan pelajar IPT. Seramai 201 pelajar daripada beberapa IPT terlibat sebagai responden dalam kajian ini. Pengkaji telah menggunakan persampelan mudah untuk mengutip data kerana kaedah ini merupakan kaedah paling mudah dimana pengkaji hanya memilih satu subjek untuk terlibat dalam kajian ini. Borang soal selidik telah diagihkan dalam salinan lembut (softcopy) dan salinan keras (hardcopy).

Hasil analisis diskriptif mendapati 25.4 peratus daripada responden merupakan pelajar lelaki manakala selebihnya, iaitu 74.6 peratus, merupakan pelajar perempuan. Rata-rata responden berumur antara 18-20 tahun (43.8\%) dan 21-24 tahun (50.2\%). Jurang perbezaan antara kedua-dua kategori umur ini hanya 6.4 peratus. Baki 6.0 peratus responden adalah mereka yang berumur 25 tahun dan keatas. Bagi peringkat pengajian pula, pelajar peringkat sarjana muda mendahului sebanyak 85.6 peratus; sesuai dengan peratusan pelajar di IPT yang sememangnya didominasi oleh pelajar sarjana muda. Peringkat pengajian kedua tertinggi adalah peringkat asasi, iaitu sebanyak 9.5 peratus dan diikuti peratusan pelajar peringkat sarjana, iaitu sebanyak 4.9 peratus.

Jadual 1 menunjukkan skor purata, skor sisihan piawai, nilai Cronbach's alpha, dan nilai korelasi. Nilai alpha yang dikira adalah untuk menilai kepercayaan ketekalan dalaman skala. Berdasarkan jadual 1, pembolehubah yang mempunyai nilai kebolehpercayaan tertinggi adalah penyerapan kognitif $(\alpha=0.912)$, diikuti oleh tabiat berinternet $(\alpha=0.833)$, dan penyalahgunaan internet $(\alpha=0.828)$. Secara keseluruhannya, nilai Cronbach's alpha untuk kesemua pembolehubah kajian adalah melebihi nilai 0.80 . 
JADUAL 1. Purata, sisihan piawai, nilai cronbach's alpha dan korelasi

\begin{tabular}{llccccc}
\hline No. & Pembolehubah & Purata & $\begin{array}{c}\text { Sisihan } \\
\text { Piawai }\end{array}$ & 1 & $\begin{array}{c}\text { Korelasi } \\
2\end{array}$ & 3 \\
\hline 1 & Penyerapan kognitif & 2.80 & 0.71 & $(.912)$ & & \\
2 & Tabiat Berinternet & 2.64 & 0.83 & $.514^{* *}$ & $(.833)$ & \\
3 & Penyalahgunaan Internet & 2.53 & 1.04 & $.481^{* *}$ & $.422^{* *}$ & $(.828)$ \\
\hline
\end{tabular}

Nota: Nilai Cronbach's alpha ditunjukkan dalam parentesis.

Jadual 1 juga menunjukkan penyerapan kognitif mencatat skor purata yang tinggi $(M=$ 2.80, S.D. $=0.71)$ berbanding tabiat berinternet $(M=2.64, S . D .=0.83)$ dan penyalahgunaan internet $(M=2.53, S . D .=1.04)$. Analisis korelasi Pearson pula menunjukkan terdapat hubungan positif yang kuat antara penyerapan kognitif dan tabiat berinternet $(r=0.514, p<$ 0.05). Manakala, hubungan antara penyerapan kognitif dan dan penyalahgunaan internet adalah sederhana $(r=0.481, p<0.05)$, begitu juga dengan hubungan antara tabiat berinternet dan penyalahgunaan internet $(0.422, p<0.05)$.

\section{HASIL ANALISIS REGRESI PENYEDERHANAAN}

Hipotesis kajian ini diuji dengan menggunakan analisis regresi penyederhanaan. Bagi mengatasi masalah multicollinearity dan memudahkan tafsiran hasil analisis, pengkaji menggunakan kaedah mean-centering seperti yang dicadangkan oleh Cohen et al. (2003). Menurut kaedah ini, nilai asal bagi satu pembolehubah tidak bersandar ditolak daripada nilai min pembolehubah tersebut untuk mendapatkan nilai baru yang dikenali sebagai centered predictor. Seterusnya, nilai-nilai baru ini didarabkan untuk menghasilkan nilai interaksi. Dalam kajian ini, nilai baru bagi penyerapan kognitif dan tabiat berinternet didarabkan dan pengkaji memperolehi satu nilai interaksi yang dilabelkan sebagai penyerapan kognitif $\times$ tabiat berinternet.

JADUAL 2. Regresi penyederhanaan penyalahgunaan internet terhadap penyerapan kognitif dan tabiat berinternet

\begin{tabular}{lccccc}
\hline Pembolehubah tidak bersandar & $R^{2}$ & F change & $\beta$ & S.E. & $p$ \\
\hline Langkah 1 & .273 & 37.174 & & & \\
$\quad$ Penyerapan kognitif & & & .360 & .089 & .000 \\
Tabat berinternet & & & .237 & .103 & .001 \\
Langkah 2 & .286 & 26.298 & & & \\
$\quad$ Penyerapan kognitif & & & .360 & .088 & .000 \\
Tabiat berinternet & & & .256 & .103 & .000 \\
Penyerapan kognitif $\times$ Tabiat berinternet & & .116 & .049 & .060 \\
\hline
\end{tabular}

Jadual 2 menunjukkan hasil analisis regresi penyederhanaan penyalahgunaan Internet terhadap penyerapan kognitif dan tabiat berinternet. Hasil mendapati terdapat hubungan yang yang signifikan antara penyerapan kognitif dengan penyalahgunaan Internet $(\beta=.360, p=$ .000). Oleh itu, hasil penemuan kajian ini menyokong hipotesis pertama $\left(\mathrm{H}_{1}\right)$. Begitu juga dengan hipotesis kedua $\left(\mathrm{H}_{2}\right)$ yang menjangka tabiat berinternet mempunyai hubungan yang signifikan dengan penyalahgunaan internet $(\beta=0.256, p=.000)$. Walau bagaimanapun, tabiat berinternet tidak bertindak sebagai penyederhana kepada hubungan penyerapan kognitif dan penyalahgunaan internet di mana $\mathrm{H}_{3}$ adalah ditolak $(\beta=0.116, p=.060)$. 


\section{PERBINCANGAN DAN KESIMPULAN}

Kajian ini bertujuan untuk menguji adakah penyerapan kognitif yang wujud ketika pelajar sedang khusyuk menggunakan internet mampu mempengaruhi penyalahgunaan internet sewaktu kuliah (Hipotesis 1). Seterusnya, kajian ini juga menguji adakah tabiat berinternet (Hipotesis 2) dan interaksi tabiat berinternet bersama penyerapan kognitif (Hipotesis 3) boleh menguatkan lagi tingkahlaku penyalahgunaan internet sewaktu kuliah.

Hipotesis pertama kajian yang menguji hubungan antara penyerapan kognitif dalam kalangan pelajar dan penyalahgunaan internet sewaktu kuliah adalah diterima. Nilai beta analisis regresi berganda memperoleh nilai 0.360 pada tahap keyakinan $95 \%$ yang membawa maksud terdapat hubungan positif dan signifikan antara penyerapan kognitif dan penyalahgunaan internet. Dapatan ini mengesahkan dan menyokong bahawa jika pelajar merasai diri mereka terputus daripada realiti, wujud perasaan ingin tahu yang tinggi, keseronokan yang melampau, fokus yang mendalam dan hilang kawalan ketika menggunakan internet, maka mereka berpotensi untuk menyalahgunakan internet (Agarwal et al. 2000). Hasil kajian ini turut menyokong kajian yang dibuat oleh Gerow et al. (2010) serta Hsu dan Lin (2017) yang menyatakan apabila pelajar terlampau tertumpu kepada teknologi internet, penyerapan kognitif lebih mudah berlaku kepada pelajar. Contohnya, apabila pelajar terlampau tertumpu kepada mesej segera (instant massaging) atau emel, pelajar dapat merasai pengalaman keseronokan berinternet sehingga tidak sedar masa yang berlalu. Oleh itu, ianya terbukti bahawa pelajar yang cenderung kognitifnya diserap dengan teknologi internet lebih positif untuk melakukan penyalahgunaan internet.

Hasil kajian ini mendapati bahawa pelajar yang mempunyai tabiat berinternet juga adalah terdorong untuk melakukan penyalahgunaan internet sewaktu kuliah. Hipotesis 2 adalah diterima apabila tabiat berinternet mempunyai hubungan yang positif dan signifikan dengan penyalahgunaan internet sewaktu kuliah. Hasil kajian adalah selari dengan beberapa kajian terdahulu yang mendapati individu yang mempunyai tabiat berinternet adalah terdorong untuk melakukan penyalahgunaan internet (Pee et al. 2008; Vitak et al. 2011). Hubungan diantara tabiat berinternet dengan penyalahgunaan internet berlaku lebih secara tanpa niat (Pee et al. 2008) dan tingkahlaku tersebut berlaku secara automatik (Blancard \& Henle 2008).

Hasil kajian yang menyokong hipotesis 1 dan hipotesis 2 mengukuhkan lagi Teori Kelemahan Regulasi-Kendiri (LaRose et al. 2003) yang menyatakan bahawa tingkahlaku yang sukar dikawal dan perbuatan yang dilakukan tanpa disedari terhadap penggunaan internet mampu menjadikan individu tersebut ketagihan internet (internet addiction) (LaRose et al. 2003) sehingga melakukan penyalahgunaan internet (Carrie 2015). Dalam kajian ini penyerapan kognitif berupaya mencetus tingkahlaku yang sukar dikawal (Agrawal \& Karahanna 2000) dan tabiat berinternet berupaya menyebabkan sesuatu perbuatan dilakukan tanpa disedari (Tokunaga 2017), dimana kedua-duanya bertindak sebagai pendorong kepada penyalahgunaan internet dalam kalangan pelajar sewaktu kuliah yang disebabkan oleh kelemahan pelajar di dalam regulasi-kendiri.

Walau bagaimanapun, hasil kajian ini tidak dapat membuktikan bahawa tabiat berinternet boleh menyederhanakan hubungan antara penyerapan kognitif dengan penyalahgunaan internet. Kajian lepas mendapati kekuatan tabiat berinternet boleh meningkat apabila seseorang itu berada dalam situasi tidak terkawal seperti kesunyian, ketidakpuasan dan kebosanan (LaRose et al. 2010). Namun, hasil kajian ini menunjukkan penyerapan kognitif mampu bertindak sendirian dalam mempengaruhi penyalahgunaan internet dalam kalangan pelajar. Tabiat berinternet tidak memainkan peranan sebagai pembolehubah penyederhana, sama ada pelajar tersebut mempunyai tabiat berinternet atau tidak, ianya tidak menguatkan atau melemahkan hubungan antara penyerapan kognitif dan penyalahgunaan 
internet. Kajian ini beranggapan bahawa apabila individu telah dikawal oleh penyerapan kognitif, maka kekuatan penyerapan tersebut berupaya mengatasi tabiat berinternet yang menyebabkan ianya tidak bertindak sebagai penyederhana. Walau bagaimanapun, hasil analisis regresi penyederhanaan yang tidak signifikan tidak bermakna tiada kesan penyederhanaan di dalam sampel kajian. Berkemungkinan ianya terjadi disebabkan ketidakcukupan bukti didalam set data (Hair et al. 2006). Namun, hasil kajian telah menunjukkan terdapat perubahan yang begitu kecil di dalam $\mathrm{R}^{2}$ iaitu dari 0.273 kepada 0.286 yang mencadangkan kesan penyederhaan dari sampel kajian adalah sangat kecil untuk menampakkan kesignifikannya.

Kajian ini juga mempunyai beberapa limitasi iaitu yang pertama, kajian ini hanya menggunakan hanya dua faktor dorongan dalaman di mana nilai regresi berganda $\left(\mathrm{R}^{2}\right)$ yang diperolehi adalah kecil. Ini bermakna terdapat banyak lagi faktor yang boleh mempengaruhi penyalahgunaan internet dalam kalangan pelajar IPT. Cadangan pengkaji untuk masa depan adalah memperbanyakkan kajian ke atas faktor dalaman dan luaran yang boleh mendorong penyalahgunaan internet dalam kalangan pelajar sewaktu kuliah, Ini bagi membolehkan pengukuran lebih tepat dilakukan seterusnya dapat membantu pihak IPT untuk memikirkan strategi mengurangkan berlakunya penyalahgunaan internet dalam kalangan pelajar sewaktu kuliah. Selain itu, kajian ini juga hanya menggunakan pembolehubah penyerapan kognitif sebagai pembolehubah peringkat kedua (second order). Dalam kajian masa depan, penyerapan kognitif perlu diuji dari setiap elemen yang dimiliki iaitu terputus daripada realiti (temporal dissociation), memberi fokus yang mendalam (immersion focus), keseronokan yang tinggi (heightened enjoyment), perasaan ingin tahu yang tinggi (curiosity) dan kawalan (control) (Agarwal \& Karahanna 2000).

Kesimpulannya, walaupun penggunaan internet dapat membantu pelajar untuk bergerak selari dengan revolusi industri 4.0 dalam semua bidang terutama dalam pelajaran, namun dalam masa yang sama ianya juga mampu menyebabkan prestasi pelajar menurun apabila pelajar tidak berdisiplin dan menyalahgunakan internet sewaktu kuliah. Penyalahgunaan internet dalam kalangan pelajar juga merupakan salah satu punca pihak universiti gagal melahirkan graduan yang berprestij dan bertaraf dunia. Hasil kajian telah membuktikan secara empirikal kewujudan penyerapan kognitif dalam kalangan pelajar semasa penggunaan internet sehingga berlakunya penyalahgunaan internet sewaktu kuliah. Malah, terdapat juga pelajar yang melakukan penyalahgunaan internet tanpa disedari kerana mereka mempunyai tabiat berinternet dan mampu melemahkan proses regulasi-kendiri.

Disamping itu, pihak IPT juga perlu memantau dan melakukan kawalan ke atas pelajar dari mengakses internet bagi tujuan peribadi sewaktu kuliah. Pihak IPT harus memainkan peranan yang lebih besar dalam meningkatkan kesedaran kepada pelajar tentang penyalahgunaan internet sewaktu kuliah serta kesannya terhadap masa depan pelajar. Pelajar perlu tahu bagaimana untuk mendisiplinkan diri sendiri tidak kira di mana mereka berada dan beretika ketika menggunakan internet. Pihak IPT juga wajar membenarkan pensyarah mengenakan tindakan tatatertib terhadap pelajar yang didapati menggunakan internet bagi tujuan peribadi sewaktu kuliah. Tujuan kawalan dan kesedaran ini adalah demi kebaikan pihak IPT sendiri amnya dan pihak pelajar khususnya kerana kegagalan yang mereka cipta disebabkan penyalahgunaan internet sewaktu kuliah mampu memadamkan harapan dan citacita mereka sendiri.

\section{RUJUKAN}

Agarwal, R. \& Karahanna, E. 2000. Time flies when you're having fun: Cognitive absorption and beliefs about information technology usage. MIS Quarterly 24(4): 665-694. 
Apuke, O.D. \& Iyendo, T.O. 2017. Two sides of a coin: revisiting the impact of social networking sites on students' performance in selected higher educational settings in Nigeria. Science International 29(6): 1265-1275.

Askew, K., Buckner J.E., Taing, M.U., Ilie A., Bauer J.A. \& Coovert M.D. 2014. Explaining cyberloafing: The role of the theory of planned behaviour. Computers in Human Behavior 36: 510-519.

Bandura, A. 1991. Social cognitive theory of self-regulation. Organizational Behavior and Human Decision Processes 50: 248-287.

Barnes, S.J. \& Pressey A.D. 2014. Caught in the web? Addictive behavior in cyberspace and the role of goal-orientation. Technological Forecasting and Social Change 86(C): 93109.

Baturay, M.H. \& Toker, S. 2015. An investigation of theimpact of demographics on cyberloafing from an educational setting angle. Computers in Human Behavior 50: 358366

Blanchard, A.L. \& Henle, C.A. 2008. Correlates of different forms of cyberloafing: The role of norms and external locus of control. Computers in Human Behavioor 24: 1067-1084.

Bonetta, P.J., Sindermann, C., Sha, P., Zhou, M. \& Montag, C. 2019. The relationship between Internet Use Disorder, depression and burnout among Chinese and German college students. Addictive Behaviors 89: 188-199.

Bozoglan, B., Demirer, V. \& Sahin, I. 2014 Problematic Internet use: Functions of use, cognitive absorption, and depression. Computers in Human Behavior 37:117-123.

Bugeja, M.J. 2007. Distractions in the wireless classroom. The Chronicle of Higher Education 53: C1-C5.

Chen, J.V., Chen, C.C. \& Yang, H.H. 2008. An empirical evaluation of key factors contributing to internet abuse in the workplace. Industrial Management \& Data Systems 108(1): 87-106.

Chiu, C.M. \& Huang, H.Y. 2015. Examining the antecedents of user gratification and its effects on ndividuals' social network services usage: The moderating role of habit. European Journal of Information Systems 24(4): 411-43.

Cohen, J., Cohen, P. West, S.G. \& Aiken, L.S. 2003. Applied Multiple Regresion/Correlation Analysis for the Behavioral Sciences. 3rd edition, New Jersey: Lawrence Erlbaum Associates.

Currie, A.V. 2015. Student use and misuse of personal technological devices in the higher education classroom. Unpublished Doctor of Education Dissertation, Graduate Faculty of North Carolina State University

Davis, R.A. 2001. A cognitive-behavioral model of pathological Internet use. Computers in Human Behavior 17: 187-195.

Fanning, E. 2005. Formatting a paper-based survey questionnaire: Best practices. Practical Assessment Research \& Evaluation 10(12): 2-14.

Flanigan, A.E. \& Kiewra, K.A. 2018. What college instructors can do about student cyberslacking? Educational Psychology Review 30(2): 585-597.

Gerow, J.E., Galluch, P.S. \& Thatcher, J.B. 2010. To slack or not to slack: internet usage in the classroom. Journal of Information Technology Theory and Application 11(3): 5-23.

Hair, J.F., Black, W.C., Babin, B.J., Anderson, R.E. \& Tatham, R.L. 2006, Multivariate Data Analysis. $6^{\mathrm{a}}$ edition. Upper Saddle River, NJ: Pearson Prentice Hall.

Hasmida J., Zauwiyah A., Mazni A. \& Maimun S. 2015. Personal internet use: The use of personal mobile devices at the workplace. Procedia Social and Behavioral Sciences 172: 495-502. 
Henderson, T., Kotz, D. \& Abyzov, I. 2004. The changing usage of a mature campus-wide wireless network. Proceedings of the 10th Annual International Conference on Mobile Computing and Networking, Philadelphia, PA. 187-201.

Henle, C.A. \& Blanchard, A.L. 2008. The interaction of work stressors and organizational sanctions on cyber loafing. Journal of Managerial Issues 20(3): 383-400.

Hsu, M.H. \& Lin, H.C. 2017. An investigation of the impact of cognitive absorption on continued usage of social media in Taiwan: the perspective of fit. Behaviour \& Information Technology 36(8): 768-791.

Hsu, Y.H., Li, C.K., Li, C.M. \& Liu, N.T. 2016. The effect of website quality features and cognitive absorption on social network site usage: A cross-national study. International Journal of Electronic Commerce Studies 7(2): 156-188.

Jia, R. 2012 Computer playfulness, internet dependency and their relationships with online activity types and student academic performance. Journal of Behavioral Addiction 1(2): 74-77.

Johns, M.W. 1992. Reliability and factor analysis of the epworth sleepiness scale. Sleep 15(4): 376-381.

Kamus Pelajar Bahasa Melayu Dewan. 2012. Edisi Kedua. Dewan Bahasa dan Pustaka: Kuala Lumpur

Kubey, R. \& Csikszentmihalyi, M. 2002. Television addiction is no mere metaphor. Scientific America 286(2): 74-80.

Kuznekoff, J.H., Munz, S. \& Titsworth, S. 2015. Mobile phones in the classroom: Examining the effects of texting, twitter, and message content on student learning. Communication Education 64(3): 344-365.

Lam, P. \& Tong, A. 2012. Digital devices in classroom: Hesitations of teachers-to-be. The Electronic Journal of e-Learning 10(4): 387-395.

LaRose, R. 2010. The problem of media habits. Communication Theory: 194-222.

LaRose, R., Kim, J.H. \& Peng, W. 2010. Social networking: Addictive, compulsive, problematic, or just another media habit? In A networked self: Identity community, and culture on social network sites, disunting oleh Z. Pappacharissi, 59-81. NY: Routledge.

LaRose, R., Lin, C.A. \& Eastin, M.S. 2003. Unregulated Internet usage: Addiction, habit, or deficient self-regulation? Media Psychology 5: 225-253.

Lee, O.K., Lim, K.H. \& Wong, W.M. 2005. Why workers do non-work-related computing: An exploratory investigation through multiple theoretical perspectives. Proceedings of the 38th Annual Hawaii International Conference, 185c-185c: IEEE.

Lim, V.K.G. 2002. The IT way of loafing on the job: Cyberloafing, neutralizing and organizational justice. Journal of Organizational Behavior 23(5): 675-694

Lim, V.K.G. \& Chen, D.J.Q. 2012. Cyberloafing at the workplace: Gain or drain on work? Behaviour \& Information Technology 31(4): 343-353.

MCMC-Malaysian Communication and Multimedia Commission. 2018. Internet Users Survey 2018: MCMC-Cyberjaya, Selangor.

Mazzoni, E., Cannata, D. \& Baiocco, L. 2016. Focused, not lost: The mediating role of temporal dissociation and focused immersion on problematic internet use. Behaviour \& Information Technology 36(1): 11-20.

McCoy, B.R. 2016. Digital distractions in the classroom phase II: Student classroom use of digital devices for non-class related purposes. Journal of Media Education 7: 5-32.

Moody, G.D. \& Siponen, M. 2013. Using the theory of interpersonal behavior to explain nonwork related personal use of the internet at work. Information and Management 50: 322335.

Niaei, M., Peidaei, M.M. \& Nasiripour, A.A. 2014. The Relation between workers cyberloafing and organizational commitment in organization of environmental 
protection. Kuwait Chapter of Arabian Journal of Business and Management Review 3(7): 59-71.

Ostrom, T.M. 1969. The relationship between the affective, behavioral, and cognitive components of attitude. Journal of Experimental Social Psychology 5(1): 12-30

Pee, L.G., Woon, I.M.Y. \& Kankanhalli, A. 2008. Explaining non-work-related computing in the workplace: A comparison of alternative models. Information \& Management 45(2): $120-130$.

Rana, N., Dwivedi, Y., Slade, E. \& Lal, B. 2016. Cyber-slacking: Exploring studens' usage of internet-enabled devices for non-class related activities. Americas Conference on Information Systems, San Diego: CA.

Ravizza, S.M., Hambrick, D.Z. \& Fenn, K.M. 2014. Non-academic internet use in the classroom is negatively related to classroom learning regardless of intellectual ability. Computers \& Education 78: 109-114.

Saunders, M., Lewis, P. \& Thornhill, A. 2012 Research Methods for Business Students. New York: Pearson Education Ltd. Harlow.

Shannon J.O.B. 2011. Facebook and other internet use and the academic performance of college students. Unpublished Thesis Doctor of Philosophy, Temple University.

Shotsberger, P.G. \& Vatter, R. 2001. Teaching and learning in the wireless classroom. Computer 34(3): 110-111

Soh P.C.H, Koay K.Y. \& Lim, V.K.G. 2018 Understanding cyberloafing by students through the lens of an extended theory of planned behaviour. Peer-Reviewed Journal on Internet 23(6): 1-18.

Tokunaga, R. 2017. A meta-analysis of the relationship between psychosocial problems and internet habits: Synthesizing internet addiction, problematic internet use, and deficient self-regulation research. Communication Monographs 84(4): 423-446.

Tokunaga, R.S. \& Rains, S.A. 2016. A review and meta-analysis examining conceptual and operational definitions of problematic Internet use. Human Communication Research 42: 165-199.

Triandis, H.C. 1980. Values, attitudes, and interpersonal behavior, In: Nebraska Symposium on Motivation in 1979: Beliefs, Attitudes and Values, disunting oleh M.M. Howe \& H.E. Page, 195-295. Lincoln: University of Nebraska Press, 195-295.

Urbaczewski, A. \& Jessup, L.M. 2002. Does electronic monitoring of employee internet usage work? Communications of the ACM 45(1): 80-83.

Vitak, J., Crouse, J. \& LaRose, R. 2011. Personal Internet use at work: Understanding cyberslacking. Computers in Human Behavior 27: 1751-1759.

Weatherbee, T.G. 2010. Counterproductive use of technology at work: Information \& communications technologies and cyber deviancy. Human Resource Management Review 20(1): 35-44.

Yasar, S. \& Yurdugul, H. 2013. The investigation of relation between cyberloafing activities and cyberloafing behaviors in higher education, Procedia-Social and Behavioral Sciences 83: 600-604.

Young, J.R. 2006. The fight for classroom attention: Professor vs. laptop. The Chronicle of Higher Education: A27-A29.

Roshayati Abdul Hamid (penulis koresponden)

Pusat Penciptaan Nilai dan Kesejateraan Insan (INSAN)

Fakulti Ekonomi dan Pengurusan

Universiti Kebangsaan Malaysia

43600 UKM Bangi, Selangor, MALAYSIA.

E-Mel: wanrose@ukm.edu.my 


\section{Zaleha Yazid}

Pusat Penciptaan Nilai dan Kesejateraan Insan (INSAN)

Fakulti Ekonomi dan Pengurusan

Universiti Kebangsaan Malaysia

43600 UKM Bangi, Selangor, MALAYSIA.

E-Mel: leyha@ukm.edu.my

Noor Hasni Juhdi

Pusat Penciptaan Nilai dan Kesejateraan Insan (INSAN)

Fakulti Ekonomi dan Pengurusan

Universiti Kebangsaan Malaysia

43600 UKM Bangi, Selangor, MALAYSIA.

E-Mel: n_hasni@ukm.edu.my

Laila Adrena Mat Kana

Fakulti Ekonomi dan Pengurusan

Universiti Kebangsaan Malaysia

43600 UKM Bangi, Selangor, MALAYSIA.

E-Mel: laila_adrena94@yahoo.com 